\title{
Entitas Aspektualitas Bahasa Daerah dan Pengintegrasiannya pada Matapelajaran Muatan Lokal di SMA
}

\author{
Sugerman ${ }^{1}$, Arifin ${ }^{2}$, Leni Marlina ${ }^{3}$ \\ 1,3 Dosen Program Studi Pendidikan Bahasa dan Sastra Indonesia, STKIP Yapis Dompu \\ 2 Dosen Program Studi Pendidikan Teknologi Informasi, STKIP Yapis Dompu \\ E-mail: sugerman.erman@gmail.com, arifinku1212@gmail.com, sayalenimarlina@gmail.com
}

Article History: Received: 2021-07-22 || Revised: 2021-07-28 || Published: 2021-08-22

Sejarah Artikel : Diterima: 2021-07-22 || Direvisi: 2021-07-28 || Dipublikasi: 2021-08-22

\begin{abstract}
This research aimed to examine the form of Bima language aspects. The form of the aspects include inchoative, perfective, and inceptive. This research was an ethnographic with a qualitative approach with data collection techniques using structured observation and note taking. Data obtained through informants who are incidental. The results of this research indicate (1) the form of the Bima language inchoative aspects is characterized by the attachment of particles $\{-\mathrm{ra}\},\{-\mathrm{ni}\},\{-\mathrm{ta}\}$, and $\{-$ pu $\}$ in basic verb; (2) the perfect form of aspiration of Bima Language is marked by the attachment of affix morphemes $\{\mathrm{ra}-\},\{-\mathrm{na}\},\{-\mathrm{ku}\},\{-\mathrm{mu}\},\{\mathrm{ra}-\mathrm{ku}\}$, \{ra-na\}, \{ma-na\}, and \{ma / ra-na in the basic verb; (3) the form of perceptive aspects is marked by the attachment of affix morphemes $\{$ ndi- $\},\{$ ndi $/$ ma- $\},\{$ na- $\},\{$ mu- $\},\{k u-\},\{$ na-ku\}, $\{$ na-ra $\},\{m u-r a\},\{$ ndi-na $\},\{m y$ ndi\}, \{your ndi\}, and \{ndi / ma-na\} in basic verbs; (4) there is a level of politeness as a marker of Bima Language inchoative aspects with a scale $(2,2.5,3$, and 5); (5) there are aspects which are categorized as passive and non-active active non-indicative aspects on the perfective and perceptive aspects; (6) there are productive and unproductive particles and affixes on inchoative, effective and perceptive aspects; inchoative aspects of productive percentage reaches $50 \%$, perfective aspects of productive and unproductive percentage starting at $10 \%$ and $30 \%$, and perceptive aspiration of productive and unproductive percentage starting at $10 \%, 40 \%$, and $60 \%$; (7) the formation of the Bima language's aspects is marked by the attachment of affixed particles and morphemes to the basic verbs meaning that the formation of aspects begin with the process of morphology.
\end{abstract}

Keywords: Aspectuality, Regional Language, Integration, Local Content

\begin{abstract}
Abstrak
Penelitian ini bertujuan untuk mengkaji bentuk aspektulitas Bahasa Bima. Bentuk aspek tersebut meliputi aspektualitas inkoatif, perfektif, dan inseptif. Penelitian ini merupakan penelitian etnografi dengan pendekatan kualitatif dengan teknik pengumpulan data menggunakan observasi terstruktur dan simak catat. Data diperoleh melalui informan yang bersifat insidental. Hasil penelitian ini menunjukkan (1) bentuk aspektualitas inkoatif bahasa Bima ditandai dengan melekatnya partikel $\{$-ra $\},\{-n i\},\{$-ta $\}$, dan $\{$-pu $\}$ pada verba dasar; (2) bentuk aspektualitas perfektif Bahasa Bima ditandai dengan melekatnya morfem afiks \{ra-\}, $\{-n a\},\{-k u\},\{-m u\},\{r a-k u\},\{r a-n a\},\{m a-n a\}$, dan $\{m a / r a-n a\}$ pada verba dasar; (3) bentuk aspektualitas inseptif ditandai dengan melekatnya morfem afiks $\{$ ndi- $\},\{$ ndi $/$ ma- $\},\{$ na- $\},\{$ mu- $\},\{k u-\},\{$ na-ku $\},\{$ na-ra $\},\{$ mura\}, \{ndi-na\}, \{ndi-ku\}, \{ndi-mu\}, dan \{ndi/ma-na $\}$ pada verba dasar; (4) terdapat tingkat kesantunan sebagai penanda aspektualitas inkoatif Bahasa Bima dengan skala (2, 2,5, 3, dan 5); (5) terdapat aspektualitas yang berkategori aspektualitas nondeiktif pasif dan nondeiktif aktif pada aspektualitas perfektif dan inseptif; (6) terdapat partikel dan afiks yang produktif dan tidak produktif pada aspektualitas inkoatif, perfektif dan inseptif; aspektualitas inkoatif presentase produktifnya mencapai 50\%, aspektualitas perfektif persentase produktif dan tidak produktifnya mulai $10 \%$ dan 30\%, dan aspektualitas inseptif presentase produktif dan tidak produktifnya mulai 10\%, 40\%, dan 60\%; (7) pembentukan aspektualitas Bahasa Bima ditandai dengan melekatnya partikel dan morfem afiks pada verba dasar artinya bahwa pembentukan aspektualits diawali dari proses morfologi.
\end{abstract}

Kata kunci: Aspektualitas, Bahasa Daerah, Integrasi, Muatan Lokal

\section{PENDAHULUAN}

Pada umumnya setiap ahli bahasa mengatakan bahwa bahasa merupakan suatu yang dapat dipisahkan dari hidup dan kehidupan masyarakat. Bahasa merupakan alat yang digunakan oleh 
individu atau kelompok dalam mengomunikasikan ide dan pikirannya dalam interaksi sosial dengan lawan tuturnya. Kedudukan bahasa sebagai alat komunikasi merupakan fitrah dari bahasa itu sendiri yang tidak dapat dipisahkan dari masyarakat sebagai makhluk sosial yang dalam kesehariannya menjadikan bahasa sebagai medium komunikasinya. Oleh karena itu, tidak heran sedari kecil setiap individu selalu berusaha untuk memelajari, menguasai, dan memahami bahasa khususnya bahasa pertama (the first language), kemudian dalam proses formal seorang anakpun mulai memelajari, menguasai dan memahami bahasa kedua (the second language).

Bahasa merupakan sistem lambang bunyi yang bersifat arbitrer yang dijadikan sebagai medium bagi individu atau kelompok sosial dalam bekerjasama, mengomunikasikan ide dan pikirannya serta menunjukkan jati diri sebagai insan yang berbahasa dan berbudaya. Melalui medium bahasa, setiap ide, pikiran dan budaya seseorang akan terungkap baik itu interaksi antara pembicara dan pendengar, penulis dan pembaca, atau pesapa kepada yang disapa. Pengungkapan bahasa dalam interaksi sosial tersebut tidak terlepas dari waktu tuturan baik dalam komunikasi lisan maupun tulisan. Hal ini sesuai dengan yang disampaikan oleh (Mazurkiewicz, 2008) bahwa di dalam bahasa itu sendiri tidak terlepas dari waktu (aspektualitas), tetapi dalam konteks pengungkapannya bahwa waktu dalam bahasa yang satu dengan bahasa yang lain berbeda. Pembedaannya dibagi menjadi dua yaitu aspek yang diungkapkan secara morfologis dan secara leksikal.

Menurut (Chaer, 2015) bahwa aspek (aspektualitas) adalah teknik untuk melihat proses penyusunan dan pembentukan waktu secara intern dalam konteks situasi, kondisi, peristiwa dan proses. Kemudian menurut (Tadjuddin, 2010) bahwa aspektualitas adalah ilmu yang memelajari sifat-sifat situasi dalam konteks luar bahasa seperti peristiwa, kejadian, situasi yang dapat dilihat dari sisi waktu yang sesuai dengan konteks penggunaan bahasa. Berdasarkan pendapat tersebut, dapat disimpulkan bahwa aspektualitas merupakan unsur-unsur di luar bahasa yang melihat bentuk-bentuk peristiwa, proses, keadaan yang sesuai dengan konteks tuturan.

Disetiap Bahasa, ditemukan istilah aspektualitas, temporalitas, dan modalitas yang merupakan bagian dari pembahasan semantik verba yang berkenaan dengan gramatikal verba. Ketiga unsur tersebut merupakan kategori gramatikal yang bersifat menyeluruh. Artinya bahwa rata-rata Bahasa yang ada di dunia mengenal istilah aspektualitas, temporalitas, dan modalitas. Namun, dalam penelitian ini peneliti hanya membahas dan mengkaji tentang aspektualitas Bahasa Bima.

Rata-rata ahli linguistik menggunakan aspektualitas dengan istilah aspek (aspect). Ada beberapa pandangan ahli linguistik tentang aspektualitas diantaranya menurut (Comrie, 1976) bahwa aspek adalah teknik mengungkapkan nilai-nilai tempo atau waktu pada aktivitas dan keadaan. Kemudian (Lyons, 1968) berpandangan bahwa aspek adalah teknik memahami waktu dalam konteks situasi dan keadaan. Lebih lanjut diungkapkan bahwa aspek adalah teknik untuk melihat pembentukan waktu di dalam konteks situasi, keadaan, kejadian, dan proses terjadinya tuturan (Chaer, 2015). Sedangkan (Nasiruddin, 2019) berpendapat bahwa penetapan waktu untuk suatu peristiwa dan kejadian tidak hanya berdasarkan kepada pembentukan kata (morfologi) verba, tetapi juga berdasarkan pada bentuk lain seperti konteks atau kata keterangan dan partikel. (Comrie, 1976) memahami aspek sebagai suatu sistem temporal di dalam situasi itu sendiri. Situasi dalam pandangannya meliputi keadaan, peristiwa, dan proses. Perbedaannya terdapat pada sifatnya, keadaan bersifat statis sedangkan peristiwa dan proses bersifat dinamis. Sedangkan menurut (Muhammad, 2016) ketiga unsur situasi tersebut memiliki hubungan. Bentuk hubungannya seperti pada diagram berikut ini.

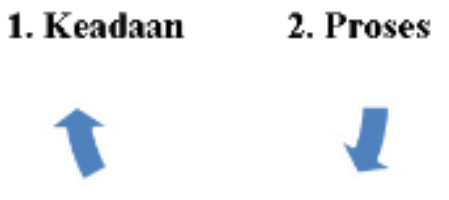

\section{Peristiwa}

Gambar 1. Hubungan Unsur Situasi Sumber. (Muhammad, 2016) 
Menurut (Renny, 2018) bahwa kategori aspek kalau dilihat dari segi luar Bahasa, menggolongkan empat jenis situasi yaitu situasi statif yang mendeskripsikan keadaan keberlangsungan tuturan di dalam unsur Bahasa itu sendiri, situasi pungtual yang mendeskripsikan peristiwa keberlangsungan tuturan, situasi aktivitas yang mendeskripsikan proses keberlangsungan tuturan, dan situasi statis yang mendeskripsikan keadaan keberlangsungan tuturan di luar unsur Bahasa. Berdasarkan uraian makna aspektualitas inheren kelas verba Bahasa Indonesia, bahwa Bahasa Indonesia memiliki empat jenis aspektualitas inheren kelas kata verba merupakan keadaan yang intern termuat pada semantic verba Bahasa Indonesia. Dengan demikian, makna aspektualitas inheren diklasifikasi menjadi empat kategori kelas kata verba yaitu kelas kata verba statif, kelas kata verba pungtual, kelas katas aktivitas, dan kelas kata verba statis.

Dalam ilmu linguistik, aspek diklasifikasi menjadi tiga subkategori gramatikal yang berkaitan dengan semantik verba. Penggolongan itu yaitu aspektualitas, temporalitas, dan modalitas. Aspektualitas dan temporalitas memelajari sifat-sifat keberlangsungan situasi yaitu gejala luar Bahasa yang berupa peristiwa, proses, aktivitas, dan keadaan) yang dilihat dari sisi waktu yang menyertai keberlangsungan keadaan tersebut. Sedangkan modalitas yaitu ilmu memelajari situsi, keadaan, proses, aktivitas dari perspektif yang bervariasi dari sikap penutur terhadap keadaan yang sedang berlangsung. Perbedaan pandangan tersebut, dapat dilihat dari bagan berikut ini.

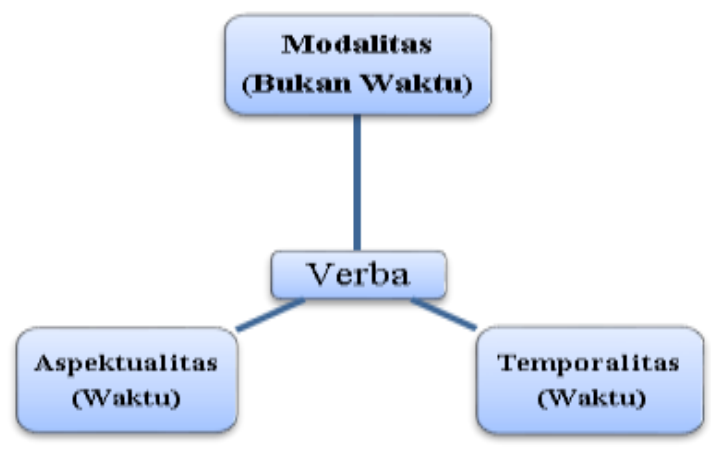

Gambar 2. Pemetaan Modalitas, Aspektualitas, dan Temporalitas Sumber. (Renny, 2018)

Dari beberapa pendapat di atas, terlihat adanya perbedaan pandangan tentang aspektualitas. Ada sebagian ahli yang memandang dari sudut pandang penutur terhadap suatu situasi (aspek), dan sebaliknya, sebagian yang lain memandang dari segi sifat situasinya (aksionalitas). Dari perbedaan pandangan tersebut. (Tadjuddin, 2010) membuat sebuah pembedaan bahwa aspek diistilahkan sebagai "kategori gramatikal (morfologi infleksional)" sedangkan aksionalitas diistilahkan sebagai "kategori leksiko gramatikal". Oleh karena itu, temporalitas dapat digolongkan sebagai unsur deiktik (unsur waktu yang bersifat eksternal) sedangkan aspektualitas dapat digolongkan sebagai unsur nondeiktik.

(Comrie, 1976) mendefinisikan aspek dari sudut pandang yang sempit yaitu masalah perspektif penutur tentang suatu situasi seperti aspek perfektif (peristiwa utuh), aspek imperfektif (sedang berlangsung), aspek inkoatif (titik awal), aspek kontinuatif (keberlanjutan), aspek egresif (titik akhir), dan aspek iteratif (keberulangan). Kemudian menurut (Tadjuddin, 2010) mengklasifikasi jenis aspektualitas menjadi 14 kategori yaitu (a) inkoatif, (b) ingresif, (c) progresif, (d) terminatif, (e) semelfaktif, (f) iteratif, (g) kontinuatif, (h) kompletif, (i) duratif, (j) intensif, (k) atenuatif, (l) diminutif, (m) finitif, dan (n) komitatif. Sedangkan Djajasudarma (2008) mengelompokkan aspektualitas menjadi 7 yaitu (a) kontinuatif, (b) inseptif, (c) progresif, (d) repetitif, (e) perfektif, (f) imperfektif, dan (g) sesatif. Namun, dalam penelitian ini, peneliti hanya mengkaji tentang pembentukan aspektualitas inkoatif, perfektif, dan inseptif Bahasa Bima.

Penelitian secara khusus mengenai aspektualitas Bahasa sudah banyak dilakukan oleh para peneliti sebelumnya. Beberapa topik kajian yang telah mereka lakukan yaitu aspektualitas melalui afiksasi, reduplikasi, tataran sintaksis, kala, aspek, maupun modus dengan menggunakan cara analisis yang 
beragam dan berbeda-beda. Ada yang mengkaji makna aspektualitas pada tataan morfologi dan sintaksis Bahasa Muna (Rahmania, 2010), (Nasiruddin, "Kala" dalam Bahasa Arab (Kajian Waktu Kebahasaan), 2019); aspek yang ditinjau dari kata kerja seperti Bahasa Bima (Rachman, 1985), (Renny, 2018) yang meneliti tentang aspektualitas dalam Bahasa Jepang dan Bahasa Indonesia. Penelitian sebelumnya menitikberatkan pada kajian secara umum tentang aspektualitas Bahasa Muna, Bahasa Arab, Bahasa Jepang dan Bahasa Indonesia serta terinklusinya kajian aspek (kala) verba secara umum pada penelitian sistem morfologi kata kerja Bahasa Bima (Rachman, 1985). Dengan demikian, penelitian ini berfokus pada makna aspektualitas bahasa Bima baik aspektualitas inkoatif, perfektif, maupun inseptif. Oleh karena itu, penelitian bertujuan untuk mengkaji bentuk dan makna aspektualitas inkoatif, perfektif, dan inseptif Bahasa Bima.

\section{METODE PENELITIAN}

Penelitian ini berjenis etnografi (ethnographic research) dengan pendekatan kualitatif yang merupakan penelitian yang mengambarkan tentang kebiasaan yang hidup dalam kelompok masyarakat atau individu tertentu melalui dokumen atau perilaku keseharian yang menggunakan pengamatan dan wawancara dalam proses pengumpulan data. Secara umum penelitian etnografi menggambarkan tentang kebiasaan kelompok masyarakat, namun dalam penelitian ini kebiasaan yang dimaksud adalah dalam penggunaan bahasa khususnya bahasa Bima.

Untuk memperoleh data dalam penelitian ini, penelitian menggunakan teknik observasi terstruktur dan simak catat sebagai teknik penggumpulan data (Mahsun, 2017). Teknik observasi ini digunakan melalui pengamatan dan pencatatan secara sistematis. Peneliti melakukan pengamatan pada proses komunikasi mahasiswa di Dompu yang berkaitan dengan bentuk aspektualitas bahasa Bima. Selain teknik itu, peneliti juga menggunakan teknik simak catat yaitu peneliti menyimak penggunaan bahasa masyarakat sehari-hari. Dalam teknik simak catat ini, ada dua teknik yang digunakan antara lain teknik simak bebas libat cakap (SBLC) yaitu peneliti hanya menyimak apa yang dibicarakan dan tanpa terlibat dalam dialog dengan pembicara, sedangkan teknik rekam digunakan sebagai alat bantu dalam proses pengumpulan data.

Data penelitian ini berupa tuturan yang mengandung bentuk-bentuk aspektualitas bahasa Bima. Aspek yang menjadi fokus penelitian yaitu aspektualitas inkoatif, perfektif, dan inseptif. Informan penelitian ini bersifat insidental artinya bahwa siapa saja yang ditemukan di wilayah penelitian yang diduga dapat memberikan informasi tentang masalah yang diteliti tetapi memenuhi syaratsyarat informan antara lain berjenis kelamin pria dan wanita, umur 20-55 tahun, dilahirkan dan dibesarkan di wilayah penelitian, dapat berbahasa Bima dan Bahasa Indonesia, serta sehat jasmani dan rohani (Mahsun, 2017).

\section{HASIL DAN PEMBAHASAN}

Dalam penelitian ini ada tiga hal yang dibahas yaitu aspektualitas inkoatif, perfektif, dan inseptif Bahasa Bima. Berikut ini akan diuraikan hasil penelitian tentang aspek inkoatif, perfektif dan inseptif Bahasa Bima.

\section{Aspektualitas Inkoatif}

Aspektualitas inkoatif merupakan aspek yang menggambarkan situasi atau keadaan yang memberikan penekanan pada permulaan aktivitas. Unsur penanda aspek ini yaitu pun dan lah, sedangkan dalam Bahasa Bima unsur penandanya yaitu $\{-r a\},\{-n i\},\{-t a\}$, dan $\{-p u\}$. Berdasarkan hasil penelitian, diperoleh data aspektualitas inkoatif sebagai berikut:

Tabel 1. Data Bentuk Aspektualitas Inkoatif Bahasa Bima

\begin{tabular}{cclll}
\hline Partikel & & $\begin{array}{l}\text { Verba Dasar } \\
(\text { Vd) }\end{array}$ & $\begin{array}{l}\text { Verba Inkoatif } \\
(\text { V+Ink) }\end{array}$ & $\begin{array}{l}\text { Makna } \\
\text { Aspektualitas }\end{array}$ \\
\hline $1 . \quad\{-r a\}$ & + & Ngaha & Ngahara & Makanlah \\
\hline 2. $\{-r a\}$ & + & Maru & Marura & Tidurlah \\
\hline $3 . \quad\{-r a\}$ & + & Lampa & Lampara & Jalanlah \\
\hline $4 . \quad\{-r a\}$ & + & Tana'o & Tana'ora & Belajarlah \\
\hline $5 . \quad\{-r a\}$ & + & Weli & Welira & Belilah \\
\hline $6 . \quad\{-n i\}$ & + & Ngaha & Ngahani & Makanlah \\
\hline
\end{tabular}




\begin{tabular}{|c|c|c|c|}
\hline 7. $\{-n i\}$ & $+\quad$ Maru & Maruni & Tidurlah \\
\hline 8. $\{-n i\}$ & $+\quad$ Lampa & Lampani & Jalanlah \\
\hline 9. $\{-n i\}$ & + Tana'o & Tana'oni & Belajarlah \\
\hline 10. $\{-n i\}$ & + Weli & Welini & Belilah \\
\hline 11. $\{-t a\}$ & $+\quad$ Ngaha & Ngahata & Makanlah \\
\hline 12. $\{-t a\}$ & + Maru & Maruta & Tidurlah \\
\hline 13. $\{-t a\}$ & $+\quad$ Lampa & Lampata & Jalanlah \\
\hline 14. $\{-t a\}$ & $+\quad$ Tana'o & Tana'ota & Belajarlah \\
\hline 15. $\{-t a\}$ & + Weli & Welita & Belilah \\
\hline 16. $\{-p u\}$ & $+\quad$ Ngaha & Ngahapu & Makanlah \\
\hline 17. $\{-p u\}$ & + Maru & Marupu & Tidurlah \\
\hline 18. $\{-p u\}$ & $+\quad$ Lampa & Lampapu & Jalanlah \\
\hline 19. $\{-p u\}$ & + Tana'o & Tana'opu & Belajarlah \\
\hline 20. $\{-p u\}$ & + Weli & Welipu & Belilah \\
\hline
\end{tabular}

Berdasarkan paparan data aspektualitas inkoatif tersebut, hasil analisis pembentukannya sebagai berikut: pembentukan aspektualitas inkoatif pada data (1), (2), (3), (4), (5) dibentuk dari (partikel+Vd=V+Ink) yaitu partikel $\{-r a\}$ berturut-turut melekat pada verba dasar ngaha, maru, lampa, hade, dan weli menjadi konstruksi ngahara, marura, lampara, tana'ora, dan welira bermakna 'makanlah, tidurlah, jalanlah, belajarlah, dan belilah'; pembentukan aspektualitas inkoatif pada data (6), (7), (8), (9), (10) dibentuk dari (partikel+Vd=V+Ink) yaitu partikel \{-ni\} berturut-turut melekat pada verba dasar ngaha, maru, lampa, hade, dan weli menjadi konstruksi ngahani, maruni, lampani, tana'oni, dan welini bermakna 'makanlah, tidurlah, jalanlah, belajarlah, dan belilah'; pembentukan aspektualitas inkoatif pada data (11), (12), (13), (14), (15) dibentuk dari (partikel+Vd=V+Ink) yaitu partikel $\{-t a\}$ berturut-turut melekat pada verba dasar ngaha, maru, lampa, hade, dan weli menjadi konstruksi ngahata, maruta, lampata, tana'ota, dan welita bermakna 'makanlah, tidurlah, jalanlah, belajarlah, dan belilah'; dan pembentukan aspektualitas pada data (16), (17), (18), (19), (20) dibentuk dari (partikel+Vd=V+Ink) yaitu partikel $\{-p u\}$ berturut-turut melekat pada verba dasar ngaha, maru, lampa, hade, dan weli menjadi konstruksi ngahapu, marupu, laтрари, tana'opu, dan welipu bermakna 'makanlah, tidurlah, jalanlah, belajarlah, dan belilah'.

Partikel pada data (1) sampai (20) memiliki makna yang sama yaitu sama-sama berkategorikan sebagai unsur partikel (lah). Namun, penanda partikel ini dalam Bahasa Bima memiliki perbedaan fungsi dalam aktivitas atau keberlangsungan tuturan. Perbedaannya terdapat pada penekanan dan tingkat kesantunan tuturan. Partikel $\{-r a\}$ berfungsi menandakan tingkat kesantunan paling rendah, partikel $\{-n i-\}$ berfungsi menandakan tingkat kesantunan rendah, partikel $\{-t a\}$ berfungsi menandakan tingkat kesantunan paling tinggi, dan partikel $\{-p u\}$ berfungsi menandakan tingkat kesantunan sedang. Tingkat kesantunan dapat digrafikan sebagai berikut.

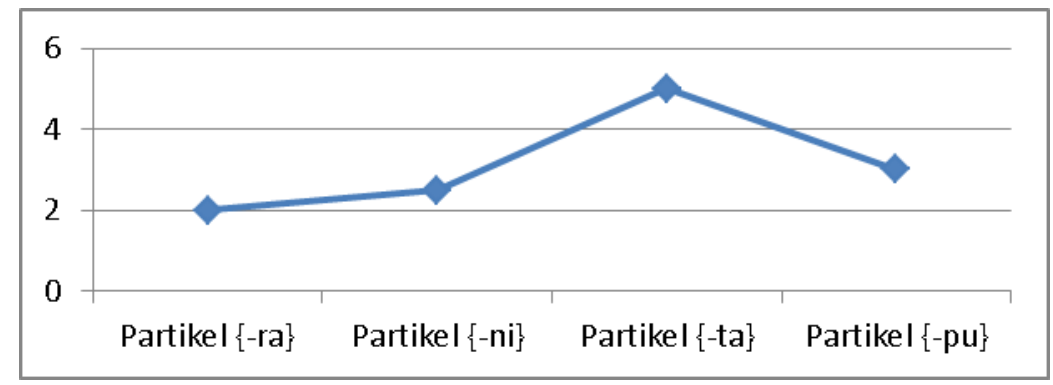

Gambar 3. Tingkat Kesantunan Penanda Aspektualitas Inkoatif Bahasa Bima

Gambar di atas menunjukkan tentang tingkat kesantunan Bahasa Bima sebagai penanda bentuk aspektualitas Inkoatif Bima dimulai dari kesantunan paling rendah, kesantunan rendah, kesantunan sedang, dan kesantunan paling tinggi. Kesantunan paling rendah berada pada skala 2 , kesantunan rendah berada pada skala 2,5, kesantunan sedang berada pada skala 3 , sedangkan 
kesantunan paling tinggi berada pada skala 5. Berdasarkan paparan data di atas, maka struktur pembentukan aspektualitas inkoatif Bahasa Bima yaitu (partikel+Vd=V+Ink). Dengan demikian, pemetaan struktur pembentukan aspektualitas tersebut dapat dilihat pada gambar berikut ini.

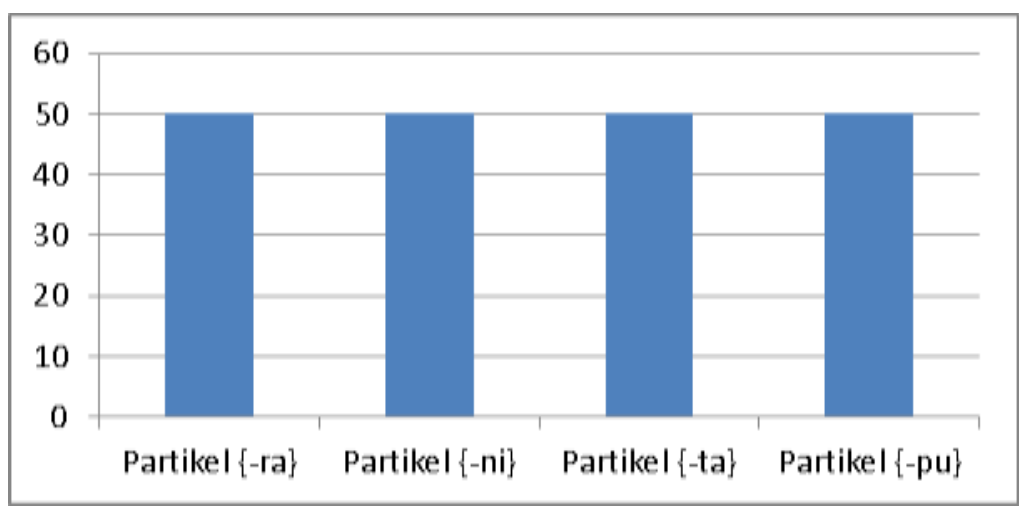

Gambar 4. Pemetaan Struktur Partikel Produktif dan Tidak Produktif

Gmbar di atas mendeskripsikan tentang produktif (Productitive particel) dan tidak produktifnya partikel (Unproductitive Particel) dalam membentuk aspektualitas inkoatif Bahasa Bima. Partikel $\{-r a\},\{-n i\},\{-t a\}$, dan $\{-p u\}$ dikategorikan sebagai kontruksi yang produktif. Rata-rata partikel tersebut dapat melekat pada verba dasar dengan presentase produktifnya rata-rata mencapai $50 \%$.

\section{Aspektualitas Perfektif}

Aspektualitas perfektif adalah bentuk waktu yang menyatakan aktivitas, kegiatan, atau proses yang sudah dilaksanakan atau telah berlangsung. Unsur leksikal penanda aspek ini yaitu konstruksi sudah atau telah. Berdasarkan hasil penelitian diperoleh data aspektualitas perfektif sebagai berikut:

Tabel 2. Data Aspektualitas Perfektif Bahasa Bima

\begin{tabular}{|c|c|c|c|c|}
\hline Afiks & & Verba Dasar (Vd) & $\begin{array}{l}\text { Verba Perfektif } \\
\text { (V+Pf) }\end{array}$ & $\begin{array}{l}\text { Makna } \\
\text { Aspektualitas }\end{array}$ \\
\hline 1. $\{r a-\}$ & + & Ngaha & Rangaha & Telah makan \\
\hline 2. $\{-n a\}$ & + & Nika & Nikana & Telah menikah \\
\hline 3. $\{-k u\}$ & + & Caki & Cakiku & $\begin{array}{l}\text { (saya) telah } \\
\text { mencoblos }\end{array}$ \\
\hline 4. $\{-m u\}$ & + & Poke & Pokemu & (dia) telah memetik \\
\hline 5. $\{r a-k u\}$ & + & dunggi & radunggiku & $\begin{array}{l}\text { (saya) telah } \\
\text { mendorong }\end{array}$ \\
\hline 6. $\{r a-n a\}$ & + & Maru & Ramaruna & Telah tidur \\
\hline 7. $\{m a-n a\}$ & + & Hade & Mahadena & $\begin{array}{l}\text { Yang telah } \\
\text { membunuh }\end{array}$ \\
\hline 8. $\{m a / r a-n a\}$ & + & Hengga & Marahenggana & Yang telah membuka \\
\hline
\end{tabular}

Berdasarkan paparan data aspektualitas perfektif tersebut, hasil analisis pembentukannya sebagai berikut: pembentukan aspektualitas perfektif pada data (1) dibentuk dari (prefiks $+\mathrm{Vd}=\mathrm{V}+\mathrm{Pf}$ ) yaitu prefiks $\{\mathrm{ra}-\}$ yang melekat pada verba dasar ngaha menjadi konstruksi rangaha bermakna 'telah makan'; pembentukan aspektualitas perfektif pada data (2) dibentuk dari (sufiks+Vd=V+Pf) yaitu sufiks $\{-n a\}$ yang melekat pada verba dasar nika menjadi konstruksi nikana bermakna 'telah menikah'; pembentukan aspektualitas perfektif pada data (3) dibentuk dari (sufiks+Vd=V+Pf) yaitu sufiks $\{-k u\}$ yang melekat pada verba dasar caki menjadi konstruksi cakiku bermakna '(saya) telah mencoblos'; pembentukan aspektualitas perfektif pada data (4) dibentuk dari (sufiks $+\mathrm{Vd}=\mathrm{V}+\mathrm{Pf}$ ) yaitu sufiks $\{-m u\}$ yang melekat pada verba dasar poke menjadi konstruksi pokemu bermakna '(dia) telah memetik'; pembentukan aspektualitas perfektif pada data (5) dibentuk dari (konfiks $+\mathrm{Vd}=\mathrm{V}+\mathrm{Pf}$ ) yaitu konfiks $\{\mathrm{ra}-\mathrm{ku}\}$ yang melekat pada verba dasar 
dunggi menjadi konstruksi radunggiku bermakna '(saya) telah mendorong'; pembentukan aspektualitas perfektif pada data (6) dibentuk dari (konfiks $+\mathrm{Vd}=\mathrm{V}+\mathrm{Pf}$ ) yaitu konfiks $\{$ ra-na\} yang melekat pada verba dasar maru menjadi konstruksi ramaruna bermakna 'telah tidur'; pembentukan aspektualitas perfektif pada data (7) dibentuk dari (konfiks+Vd=V+Pf) yaitu konfiks \{ma-na\} yang melekat pada verba dasar hade menjadi konstruksi mahadena bermakna 'yang telah membunuh'; dan pembentukan aspektualitas perfektif pada data (8) dibentuk dari (konfiks ganda+Vd=V+Pf) yaitu konfiks $\{m a / r a-n a\}$ yang melekat pada verba dasar hengga menjadi konstruksi marahenggana bermakna 'yang telah membuka'.

Ditinjau dari kategori aktif dan pasif pada data di atas yaitu data (1) dan (6) menunjukkan kategori aspektualitas nondeiktif pasif, sedangkan data (2), (3), (4), (5), (7), dan (8) menunjukkan kategori aspektualitas nondeiktif aktif. Dalam Bahasa Indonesia, proses pembentukan aspektualitas perfektif ditandai penanda deiktik dan nondeiktik waktu seperti kata telah, sudah, kemarin, dan lain-lain, sedangkan dalam Bahasa Bima, pembentukan aspektualitas ditandai dengan melekatnya morfem afiks pada verba dasar sebuah kata. Dengan kata lain, bahwa pembentukan aspektualitas Bahasa Bima diawali dari proses morfologis. Hal ini sesuai dengan pendapat (Sugerman, 2019) bahwa pembentukan morfologi Bahasa Bima tidak hanya melalui proses afiksasi, reduplikasi, komposisi tetapi juga melalui pembentukan aspektualitas, modalitas, dan temporalitas.

Berdasarkan paparan data di atas, maka struktur pembentukan aspektualitas perfektif Bahasa Bima yaitu (prefiks+Vd=V+Pf), (sufiks $+\mathrm{Vd}=\mathrm{V}+\mathrm{Pf}$ ), (konfiks+Vd=V+Pf), dan (konfiks ganda $+\mathrm{Vd}=\mathrm{V}+\mathrm{Pf}$ ). Dengan demikian, pemetaan struktur pembentukan aspektualias tersebut dapat dilihat pada gambar berikut ini.

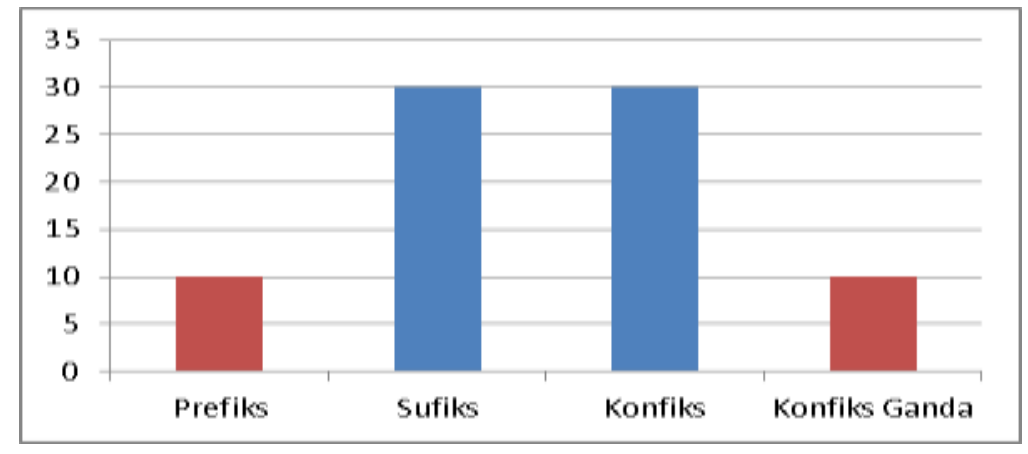

Gambar 5. Pemetaan Struktur Afiks Produktif dan Tidak Produktif

Gambar di atas, mendeskripsikan tentang produktif (Productitive Affix) dan tidak produktifnya afiks (Unproductitive Affix) dalam membentuk aspektualitas perfektif Bahasa Bima. Prefiks $\{r a-\}$ dan konfiks ganda $\{m a / r a-n a\}$ dikategorikan sebagai afiks tidak produktif karena hanya mampu membentuk aspektualitas perfektif. Prefiks $\{\mathrm{ra}-\}$ dan konfiks ganda $\{\mathrm{ma} / \mathrm{ra}$-na $\}$ presentase produktifnya hanya $10 \%$. Sedangkan sufiks $\{-n a\},\{-k u\} .\{-m u\}$ dan konfiks $\{r a-k u\} .\{r a-n a\},\{m a-$ $n a\}$ dikategorikan sebagai afiks produktif karena pembentukan aspektualitas perfektif dapat dibentuk dari berbagai macam afiks (sufiks dan konfiks). Sufiks $\{-n a\},\{-k u\},\{-m u\}$ konfiks $\{r a-$ $k u\},\{r a-n a\}$, dan $\{m a-n a\}$ presentase produktifnya mencapai $30 \%$.

\section{Aspektualitas Inseptif}

Aspektualitas inseptif adalah bentuk waktu yang menyatakan aktivitas, kegiatan, atau proses yang belum atau akan dilaksanakan. Unsur leksikal sebagai penanda bentuk aspek ini yaitu akan atau baru mulai. Berdasarkan hasil penelitian, diperoleh data aspektualitas inseptif sebagai berikut:

Tabel 3. Data Aspektualitas Inseptif Bahasa Bima

\begin{tabular}{lllll}
\hline Afiks & Verba Dasar (Vd) & $\begin{array}{l}\text { Verba Inseptif } \\
\text { (V+Ins) }\end{array}$ & Makna Aspektualitas \\
\hline $1 . \quad\{n d i-\}$ & + & Lambo & Ndilambo & Akan dipukul \\
\hline $2 . \quad\{n d i / m a-\}$ & + & $L a m b o$ & Ndimalambo & Yang akan memukul \\
\hline
\end{tabular}




\begin{tabular}{|c|c|c|c|}
\hline 3. $\{n a-\}$ & + Weli & Naweli & Akan membeli \\
\hline 4. $\{m u-\}$ & $+\quad$ Ndeu & Mundeu & (kamu) akan mandi \\
\hline 5. $\{k u-\}$ & + Maru & Kumaru & (saya) akan tidur \\
\hline 6. $\{n a-k u\}$ & $+B a b u$ & Nababuku & (dia) akan terjun \\
\hline 7. $\{n a-r a\}$ & $+\quad$ Ngaha & Nangahara & Akan segera makan \\
\hline 8. $\{m u-r a\}$ & + Ncao & Muncaora & Akan berantam \\
\hline 9. $\{$ ndi-na\} & + Weli & Ndiwelina & Yang akan (dia) beli \\
\hline 10. $\{n d i-k u\}$ & $+\underline{\text { dunggi }}$ & ndidunggiku & Yang akan (saya) dorong \\
\hline 11. $\{n d i-m u\}$ & $+t u \underline{b a}$ & Nditubamu & Yang akan (kamu) tusuk \\
\hline 12. $\{n d i / m a-n a\}$ & $+\quad t u b a$ & Ndimatubana & Yang akan menusuk \\
\hline
\end{tabular}

Berdasarkan paparan data aspektualitas inseptif tersebut, hasil analisis pembentukannya sebagai berikut: pembentukan aspektualitas inseptif pada data (1) dibentuk dari (prefiks+Vd=V+ins) yaitu prefiks $\{n d i-\}$ yang melekat pada verba dasar lambo menjadi konstruksi ndilambo bermakna 'akan dipukul'; pembentukan aspektualits inseptif pada data (2) dibentuk dari (prefiks ganda $+\mathrm{Vd}=\mathrm{V}+\mathrm{ins}$ ) yaitu prefiks $\{\mathrm{ndi} / \mathrm{ma}-\}$ yang melekat pada verba dasar lambo menjadi konstruksi ndimalambo bermakna 'yang akan memukul'; pembentukan aspektualitas inseptif pada data (3) dibentuk dari (prefiks $+V d=V+i n s)$ yaitu prefiks $\{n a-\}$ yang melekat pada verba dasar weli menjadi konstruksi naweli bermakna 'akan membeli'; pembentukan aspektualitas inseptif pada data (4) dibentuk dari (prefiks+Vd=V+ins) yaitu prefiks $\{m u-\}$ yang melekat pada verba dasar ndeu menjadi konstruksi mundeu bermakna '(kamu) akan mandi'; pembentukan aspektualitas inseptif pada data (5) dibentuk dari (prefiks+Vd=V+ins) yaitu prefiks $\{k u-\}$ yang melekat pada verba dasar maru menjadi konstruksi kumaru bermakna '(saya) akan tidur'; pembentukan aspektualitas inseptif pada data (6) dibentuk dari (konfiks+Vd=V+ins) yaitu konfiks $\{n a-k u\}$ yang melekat pada verba dasar $b a b u$ menjadi konstruksi nababuku bermakna '(dia) akan terjun'; pembentukan aspektualitas inseptif pada data (7) dibentuk dari (konfiks+Vd=V+ins) yaitu konfiks \{na-ra\} yang melekat pada verba dasar ngaha menjadi konstruksi nangahara bermakna 'akan segera makan'; pembentukan aspektualitas inseptif pada data (8) dibentuk dari (konfiks+Vd=V+ins) yaitu konfiks $\{m u-r a\}$ yang melekat pada verba dasar ncao menjadi konstruksi muncaora bermakna 'akan berantam'; pembentukan aspektualitas inseptif pada data (9) diibentuk dari (konfiks+Vd=V+ins) yaitu konfiks $\{n d i-n a\}$ yang melekat pada verba dasar weli menjadi konstruksi ndiwelina bermakna 'yang akan (dia) beli'; pembentukan aspektualitas inseptif pada data (10) dibentuk dari (konfiks $+\mathrm{Vd}=\mathrm{V}+\mathrm{ins}$ ) yaitu konfiks (ndi-ku) yang melekat pada verba dasar $\underline{\text { dunggi menjadi }}$ konstruksi ndidunggiku bermakna 'yang akan (saya) dorong'; pembentukan aspektualitas inseptif pada data (11) dibentuk dari (konfiks+Vd=V+ins) yaitu konfiks $\{n d i-m u\}$ yang melekat pada verba dasar tuba menjadi konstruksi nditubamu bermakna 'yang akan (kamu) tusuk'; dan pembentukan aspektualitas inseptif pada data (12) dibentuk dari (konfiks ganda+Vd=V+ins) yaitu konfiks $\{n d i+m a-n a\}$ yang melekat pada verba dasar tuba menjadi konstruksi ndimatubana bermakna 'yang akan menusuk'.

Ditinjau dari kategori aktif dan pasif pada data di atas yaitu data (1), (4), (5), (6), (7), (9), (10), dan (11) menunjukkan kategori aspektualitas nondeiktik pasif sedangkan data (2), (3), (8), dan (12) menunjukkan kategori aspektualitas nondeiktif aktif. Seperti yang dijelaskan sebelumnya, bahwa pembentukan proses pembentukan aspektualitas inseptif ditandai dengan adanya unsur leksikal akan atau baru dimulai. Beda halnya dengan Bahasa Bima, pembentukan aspektualitas inseptif ditandai dengan melekatnya morfem afiks pada verba dasar. Artinya bahwa pembentukan aspektualitas inseptif diawali dari proses morfologis. Hal ini sesuai dengan pendapat (Sugerman, 2019) bahwa pembentukan morfologi Bahasa Bima tidak hanya melalui proses afiksasi, reduplikasi, komposisi tetapi juga melalui pembentukan aspektualitas, modalitas, dan temporalitas.

Berdasarkan paparan data di atas, maka struktur pembentukan aspektualitas inseptif Bahasa Bima yaitu (prefiks $+\mathrm{Vd}=\mathrm{V}+\mathrm{Ins}$ ), (prefiks ganda $+\mathrm{Vd}=\mathrm{V}+\mathrm{Ins}$ ), (konfiks $+\mathrm{Vd}=\mathrm{V}+\mathrm{Ins}$ ), dan (konfiks ganda $+\mathrm{Vd}=\mathrm{V}+\mathrm{Ins})$. Dengan demikian, pemetaan struktur pembentukan aspektualias tersebut dapat dilihat digambar berikut ini. 


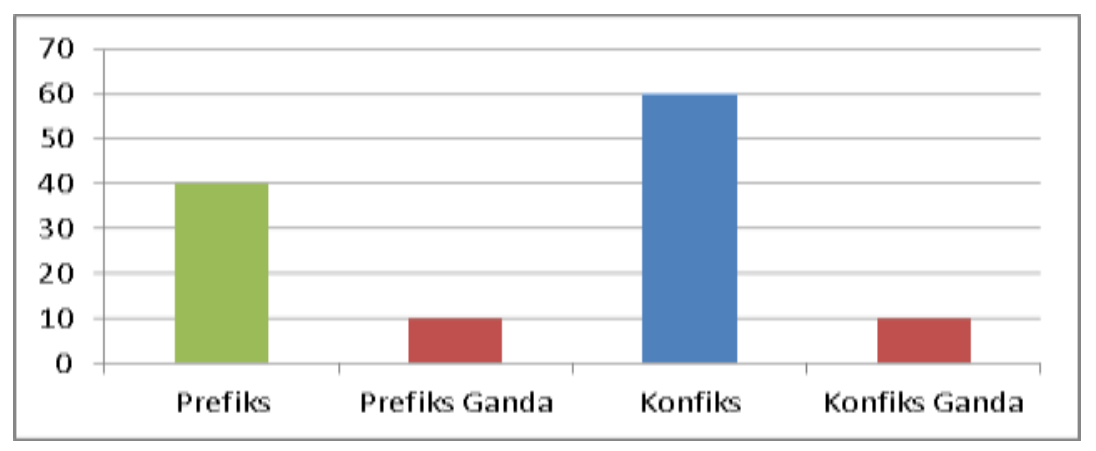

Gambar 6. Pemetaan Struktur Afiks Produktif dan Tidak Produktif

Gambar di atas, mendeskripsikan tentang produktif (Productitive Affix) dan tidak produktifnya afiks (Unproductitive Affix) dalam membentuk aspektualitas inseptif Bahasa Bima. Prefiks \{ndi-\}, $\{n a-\},\{m u-\}$, dan $\{k u-\}$ dikategorikan sebagai afiks produktif karena pembentukan aspektualitas inseptif dapat dibentuk dari berbagai macam morfem afiks dengan persentase produktifnya mencapai 40\%; konfiks $\{n a-k u\},\{n a-r a\} .\{m u-r a\},\{n d i-n a\},\{n d i-k u\},\{n d i-m u\}$ dikategorikan sebagai afiks produktif karena pembentukan aspektualitas inseptif dapat dibentuk dari berbagai macam morfem afiks dengan presentase produktifnya mencapai $60 \%$. Sedangkan prefiks ganda \{ndi/ma-\} dan konfiks ganda $\{n d i / m a-n a\}$ dikategorikan sebagai afiks tidak produktif karena hanya mampu membentuk aspektualitas inseptif dengan presentase produktifnya masingmasing hanya $10 \%$.

Dalam penelitian ini, peneliti menemukan tiga bentuk aspektualitas Bahasa Bima yaitu aspektualitas inkoatif, aspektualitas perfektif, dan aspektualitas inseptif. Proses pembentukan jenis-jenis aspektualitas Bahasa Bima ditandai dengan melekatnya morfem afiks dan partikel pada verba dasar. Penelitian ini sejalan dengan penelitian hasil (Rachman, 1985) yang mengatakan bahwa dalam Bahasa Bima terdapat kala (aspek) menunjuk pada keterangan waktu yang menandai sekarang, lampau, dan yang akan datang. (Rachman, 1985) menjelaskan hanya pada bentuk kala dalam waktu sekarang, lampau, dan yang akan datang yang batasan kajiannya hanya pada pembentukan kala Bahasa Bima. Berbeda dengan hasil penelitian ini yaitu menjelaskan tentang aspektualitas inkoatif, perfektif, dan inseptif. Penelitian ini, tidak hanya menjelaskan tentang proses pembentukan aspektualitas Bahasa Bima yang diawali dari proses morfologi tetapi juga menjelaskan tentang tingkat kesantunan berbahasa serta memetakan struktur afiks dan partikel yang produktif dan tidak produktif. Selain itu, dalam penelitian yang dilakukan (Rachman, 1985) yang menjadi informannya adalah mahasiswa di Dompu secara umum, tetapi dalam penelitian ini informannya dibatasi hanya pada masyarakat Dompu dan Bima.

\section{SIMPULAN DAN SARAN}

\section{A. Simpulan}

Secara umum, penelitian ini menemukan tiga bentuk aspektualitas Bahasa Bima yaitu aspektualitas inkoatif, aspektualitas perfektif, dan aspektualitas inseptif. Pertama, pembentukan aspektualitas inkoatif Bahasa Bima ditandai dengan melekatnya partikel $\{-r a\},\{-n i\},\{-t a\}$, dan $\{-p u\}$ pada verba dasar dengan struktur pembentukannya yaitu (partikel+Vd=V+Ink). Melekatnya partikel tersebut pada verba dasar menyebabkan terjadinya perbedaan tingkat kesantunan, partikel $\{-r a\}$ berfungsi menandakan tingkat kesantunan paling rendah yang berada pada skala 2, partikel $\{-n i\}$ berfungsi menandakan tingkat kesantunan rendah yang berada pada skala 2,5, partikel $\{-t a\}$ berfungsi menandakan tingkat kesantunan paling tinggi yang berada pada skala 5, dan partikel $\{-p u\}$ berfungsi menandakan kesantunan sedang yang berada pada skala 3. Ditinjau dari produktif dan tidak produktifnya partikel tersebut, bahwa partikel yang membentuk aspektualitas inkoatif Bahasa bima dikategorikan sebagai konstruksi yang produktif; Kedua, pembentukan aspektualitas perfektif Bahasa Bima ditandai dengan melekatnya morfem afiks $\{r a-\},\{-n a\},\{-k u\},\{-m u\},\{r a-k u\}$, $\{r a-n a\},\{m a-n a\}$, dan $\{m a / r a-n a\}$ pada verba dasar dengan struktur pembentukannya yaitu (prefiks $+\mathrm{Vd}=\mathrm{V}+\mathrm{Pf}$ ), (sufiks $+\mathrm{Vd}=\mathrm{V}+\mathrm{Pf}$ ), (konfiks+Vd=V+Pf), dan (konfiks ganda+Vd=V+Pf). Ditinjau 
dari produktif dan tidak produktifnya, bahwa morfem afiks (prefiks dan konfiks ganda) pembentuk aspek tersebut dikategorikan sebagai afiks yang tidak produktif dengan presentase $10 \%$ dan morfem afiks (sufiks dan konfiks) dikategorikan produktif dengan presentase 30\%; Ketiga, pembentukan aspektualitas inseptif Bahasa Bima ditandai dengan melekatnya morfem afiks \{ndi-\}, $\{n d i / m a-\},\{n a-\},\{m u-\},\{k u-\},\{n a-k u\},\{n a-r a\},\{m u-r a\},\{n d i-n a\},\{n d i-k u\},\{n d i-m u\}$, dan $\{n d i / m a-$ na\} pada verba dasar dengan struktur pembentukannya yaitu (prefiks $+\mathrm{Vd}=\mathrm{V}+\mathrm{ins}$ ), (prefiks ganda $+\mathrm{Vd}=\mathrm{V}+\mathrm{Ins}$ ), (konfiks $+\mathrm{Vd}=\mathrm{V}+\mathrm{Ins}$ ), dan (konfiks ganda $+\mathrm{Vd}=\mathrm{V}+\mathrm{Ins})$. Ditinjau dari produktif dan tidak produktifnya, bahwa morfem afiks (prefiks dan konfiks) sebagai pembentuk aspek tersebut dikategorikan sebagai afiks yang produktif dengan persentasenya mencapai $40 \%$ sampai $60 \%$ dan morfem afiks (prefiks ganda dan konfiks ganda) dikategorikan sebagai afiks tidak produktif dengan persentase produktifnya hanya 10\%; Keempat, ditinjau dari kategori aktif dan pasif ditemukan bahwa aspektualitas bahasa terdapat aspektualits nondeiktif pasif dan nondeiktif aktif; dan Kelima, pembentukan aspektualitas Bahasa Bima, baik aspektualitas inkoatif, aspektualitas perfektif maupun aspektualitas inseptif ditandai dengan melekatnya morfem afiks pada verba dasar, artinya bahwa pembentukan aspektualitas Bahasa Bima harus diawali dari proses morfologi.

\section{B. Saran}

Karakteristik dan eksistensi setiap Bahasa tidak terbatas oleh ruang dan waktu, ia bersifat dinamis dan arbitrer seiring dengan perkembangan peradaban dan pemikiran manusia. Dimasa sekarang dan masa yang akan datang masalah-masalah kebahasaan sangat kompleks untuk diteliti, khususnya Bahasa daerah Bima yang masih minim hasil penelitian yang dipublikasikan. Hasil penelitian ini, masih jauh dari kesempurnaan karena hanya dibatasi pada tiga bentuk aspektualitas, masih dibutuhkan kajian-kajian tentang bentuk-bentuk aspektualitas lain yang dimiliki oleh Bahasa Bima di masa yang akan datang. Demikian pula pada setting penelitian, tidak hanya dibatasi pada skala desa saja tetapi dapat menjadikan setting penelitian pada skala yang lebih luas lagi agar tercipta hasil penelitian lanjutan yang kompherensif.

Adapun saran yang dapat disampaikan dari hasil penelitian ini yaitu (1) guru muatan lokal dapat mengintegrasikan materi-materi Bahasa daerah Bima pada kurikulum serta dapat menyusun materi ajar muatan lokal yang berbasis Bahasa daerah, (2) bagi sekolah, dapat merumuskan materimateri ajar muatan lokal dalam kegiatan guru matapelajaran (MGPM), (3) bagi akademisi, kiranya dapat mengembangkan bahan ajar muatan lokal dengan mengintegrasikan materi Bahasa daerah Bima, dan (4) bagi masyarakat, kiranya dapat mengggunakan Bahasa daerah Bima secara masif dan terstruktur dalam setiap aktivitas sehingga Bahasa daerah dipertahankan dan dilestarikan.

\section{DAFTAR RUJUKAN}

Amin, M. S. (2000). Sastra Daerah Dompu dalam Kedudukannya sebagai Seni dan Adat Budaya Rakyat. Dompu: Dompu Press.

Badrun, A. (2014). Patu Mbojo: Struktur, Konsep Pertunjukan, Proses Penciptaan, dan Fungsi. Mataram : Lengge Press.

Chaer, A. (2015). Linguistik Umum. Jakarta: Rineka Cipta.

Comrie, B. (1976). Tense. Departement of Linguistics University of Southern. California: Cambridge University Press.

Finnegan, R. (1992). Oral Tradition and the Verbal Arts. London: Routledge.

Goody, J., \& Waat, I. (2000). Consequencies of Literacy. England: Penguin.

Lyons, J. (1968). Introduction to Theoritical Linguistics. London: Cambridge University Press.

Mahsun. (2017). Metode Penelitian Bahasa: Tahapan Strategi, Metode, dan Tekniknya. Jakarta: Raya Grafindo.

Mazurkiewicz, A. (2008). A Formal Deskription of Temporality (Petri Net Approach). In Lexicographic Tools and Technique. Moscow: IITP RAS. 
Muhammad, M. (2016). Kajian Semantik Arab Klasik dan Kontemporer. Jakarta: Pranadamedia Grup.

Nasiruddin. (2019). "Kala" dalam Bahasa Arab (Kajian Waktu Kebahasaan). Alfazuna, 3(2), 233243.

Rachman, A. d. (1985). Sistem Morfologi Kata Kerja Bahasa Bima. Jakarta: Pusat Pembinaan dan Pengembangan Bahasa Depdikbud.

Rahmania. (2010). Aspektualitas dalam Bahasa Muna. Kendari: Kantor Bahasa Provinsi Sulawesi Tenggara.

Renny, A. (2018). Aspektualitas dalam Bahasa Jepang dan Bahasa Indonesia. Prosiding Seminar Nasional Bahasa Ibu (SNBI) XI. 3, pp. 73-87. Denpasar-Bali: Badan Pengembangan dan Pembinaan Bahasa, Asosiasi Peneliti Bahasa-Bahasa Lokal (APBL).

Sugerman. (2019). /K/P/T/S/: An Initial Consonant of Morphophonemic Inconsistency. Seminar Tahunan Linguistik (SETALI) (pp. 951-958). Yogyakarta: Universitas Pendidikan Indonesia.

Sugerman. (2020). Kajian Bahasa: Telaah Ke Arah Linguistik Deskriptif. Yogyakarta: DePublish.

Tadjuddin, M. (2010). Aspektualitas dalam Kajian Linguistik. Bandung: Alumni. 